\title{
EFFECT OF SUPPLEMENTATION WITH PROBIOTICS ON COLONIC ANASTOMOSES IN RATS: MORPHOLOGICAL AND TENSIOMETRIC STUDY
}

\author{
Efeito da suplementação com probióticos em anastomoses colônicas de ratos: estudo morfológico e tensiométrico
}

\author{
Tiago Jacometo Coelho de CASTILHO ${ }^{1 \oplus}$, Gustavo Henrique Doná Rodrigues de ALMEIDA ${ }^{2}$, Eneri Vieira \\ de S. L. MELLO ${ }^{2 \oplus}$, Antônio Carlos L. CAMPOS ${ }^{1 \odot}$
}

\begin{abstract}
Background: The use of probiotics positively modifies the composition and function of intestinal flora, improving the quality of intestinal anastomosis. Aim: To evaluate the impact of probiotic use on intestinal anastomosis of rats. Method: Thirty-six adult male Wistar rats (Rattus norvegicus albinus, Rodentia Mammalia) were used, with body weight ranging from 220-320 g. The animals were housed and acclimated individually in boxes receiving water and ration ad libitum. After initial acclimatization, the control group received perioperative ration ad libitum for 12 days (seven preoperatively and five postoperatively) associated with the maltodextrin formula at a dose of $250 \mathrm{mg} /$ day in isocaloric and isovolumetric form. Likewise, the probiotic group received oral supplementation of probiotics dose of $250 \mathrm{mg} /$ day, associated with isocaloric and isovolumetric diet. The probiotic chosen for this study was composed of strains (doses $1 \times 10^{9}$ CFU/g) 12 Lactobacillus paracasei LPC-37, Bifidobacterium lactis HN0019, Lactobacillus rhamnosus HN001 and Lactobacillus acidophilus NCFM. Probiotics or placebo were administered orally with the aid of a dosimeter spatula. Both groups underwent two colostomies, one in the right colon and the second in rectosigmoid, followed by reanastomosis with eight separate 6-0 mononylon stitches. The sacrifice took place on the fifth day. The parameters evaluated included tensile strength, histology and collagen densitometry. Results: The rate of intestinal fistula for the control and probiotic groups were, respectively, $22.22 \%$ and $11.11 \%(p=0.6581)$.Perioperative supplementation with probiotics increased collagen deposition of types I and III $(p<0.0001)$ improved maximum traction force and maximum rupture force, $p=0.0250$ and $p=0.0116$ respectively, fibrosis area $(p<0.0001)$, and area of the inflammatory infiltrate $(p=0.0115)$. Conclusions: The use of probiotics had a positive impact on the quality of intestinal anastomosis. HEADINGS-Probiotic. Wound healing. Colonic anastomosis. Tensiometers. Collagen densitometry. Rats.
\end{abstract}

RESUMO - Racional: A utilização de probióticos modifica positivamente a composição e função da flora intestinal melhorando a qualidade da anastomose intestinal. Objetivo: Avaliar o impacto da utilização de probióticos na anastomose intestinal de ratos. Método: Foram utilizados 36 ratos Wistar (Rattus norvegicus albinus, Rodentia Mammalia), machos adultos, com peso corporal variando entre 220 e $320 \mathrm{~g}$. Os animais foram alojados e aclimatados individualmente em caixas recebendo água e ração ad libitum. Após aclimatação inicial, o grupo controle recebeu perioperatoriamente ração ad libitum por 12 dias (sete no pré-operatório e cinco no pós-operatório) associado à fórmula de maltodextrina na dose de $250 \mathrm{mg} /$ dia de forma isocalórica e isovolumétrica. Na semana que precedeu o procedimento cirúrgico (período de sete dias) e no pós-operatório (por cinco dias), os ratos do grupo estudo receberam suplementação via oral de probióticos dose de $250 \mathrm{mg} / \mathrm{dia}$, associado à dieta isocalórica e isovolumétrica. O probiótico utilizado era composto pelas cepas (doses $1 \times 10^{9} \mathrm{UFC} / \mathrm{g}$ ) ${ }^{12}$ Lactobacillus paracasei LPC-37, Bifidobacterium lactis HN0019, Lactobacillus rhamnosus HN001 e Lactobacillus acidophilus NCFM. A administração de probiótico ou placebo foi realizada via oral, com auxílio de espátula com dosímetro. Os dois grupos foram submetidos à duas colostomias, uma em cólon direito e outra em retossigmóide, seguido de reanastomose com oito pontos separados de mononylon 6-0. O sacrifício ocorreu no quinto dia. Os parâmetros avaliados incluíram força tênsil, histologia e densitometria do colágeno. Resultados: A taxa de fístula intestinal para os grupos controle e probiótico foram, respectivamente, $22,22 \%$ e 11,11\% ( $p=0.6581)$. A suplementação peroperatória com probióticos aumentou a deposição de colágeno dos tipos I e III $(p<0.0001)$, melhorou a força máxima de tração e força máxima de ruptura, $p=0,0250$ e $p=0,0116$ respectivamente, área de fibrose $(p<0.0001)$, e área do infiltrado inflamatório $(p=0.0115)$. Conclusões: A utilização de probióticos impactou positivamente na qualidade da anastomose intestinal.

DESCRITORES: Probiótico. Cicatrização ferida. Anastomose colônica. Tensiômetro. Densitometria do colágeno. Ratos.

\section{Central message}

Supplementation with probiotics in animal models showed beneficial effects on the tissue repair process of the intestinal wall of colonic anastomoses.

Perspective
The administration of probiotics in the pre- and
postoperative period to colon surgery proved to
be safe and favorable in the healing process in
animal models and demonstrated the potential for
such supplementation to be applied in humans,
especially in surgical situations in which the patient is
weakened, and may favor greater recovery and avoid
post-surgical complications.

From the ${ }^{1}$ Programa de Pós-Graduação em Clínica Cirúrgica, Setor Ciências da Saúde, Universidade Federal do Paraná, Curitiba, PR, Brasil, e ²Laboratório de Histotécnica Animal, Departamento de Ciências Morfofisiológicas, Universidade Estadual de Maringá, Maringá, PR, Brasil ('Postgraduate Program in Surgical Clinic, Health Sciences Sector, Federal University of Paraná, Curitiba, PR, Brazil; and ² Animal Histotechnical Laboratory, Department of Morphophysiological Sciences, State University of Maringá, Maringá, PR, Brazil).

How to cite this article: de-Castilho TJC, de-Almeida GHDR, Mello EVSL, Campos ACL. Effect of supplementation with probiotics on colonic anastomoses in rats: morphological and tensiometric study. ABCD Arq Bras Cir Dig. 2020;33(4):e1550. DOI: /10.1590/0102-672020200004e1550

Correspondence:

Tiago Jacometo Coelho de Castilho

E-mail: ticastilho@yahoo.com.br
Financial source: Coordenação de Aperfeiçoamento de Nível Superior (CAPES) - Programa de Demanda Social - 88882.381919/2019-01 Conflict of interest: none

Received for publication: 12/07/2020

Accepted for publication: 03/10/2020 
INTRODUCTION

$P$ robiotics, in a broad definition, can be considered dietary substances that promote changes in the composition and/or activity of the gastrointestinal microbiota that end up conferring benefits to the health of the host. In order to understand the role of probiotics in homeostasis and health, it is important to note that the human gastrointestinal tract hosts more than 500 species of bacteria, totaling a weight of approximately $1 \mathrm{~kg}$, with a proportion of 10 bacteria for each human cell. The bacterial genome can be present in the proportion of 100:1, and more than $10 \%$ of the daily energy required by an individual can be derived from bacterial fermentation $4,7,11,18$.

Strictly speaking, they are live bacteria or specific yeasts that meet criteria: non-pathogenicity, ability to antagonize pathogenic bacteria, resistance to gastric acidity or lysis by bile, adhesion to the epithelium, being a source of modulation of host immunity and having the ability to remain stable during processing and storage $^{3,6}$

It was believed that the benefits of probiotics came mainly from promoting the balance of the intestinal microbiota; however, there is increasing evidence that they also play an important immunomodulatory function ${ }^{3,30}$.

Initially, without the presence of any type of bacteria in our gastrointestinal tract - and therefore, without antigens for the development of tolerance and immunity -, our defense system begins to develop in the lymphoid tissue associated with the gastrointestinal tract, whose exposure early to microbial antigens promotes their colonization to the point that at four years of age we already have a stable microbiome configuration ${ }^{3}$.

In this process, we have the intraluminal conversion of components of our diet through the already colonized gastrointestinal tract. The diet modulates the microbiota, the changes being verified by experimental models in rats. An example of this is the fact that a diet rich in fats increases the proportion of Clostridium ramosum and a reduction in the proportion of bacterioids ${ }^{9,27}$. The levels of serotonin, a neurotransmitter derived from tryptophan, were modulated by the colonization of Bifidobacterium infantis, which increased their serum bioavailability and frontal cortex in rats ${ }^{2,5}$. Other important actions described are that probiotics and their metabolites reduce the secretion of the autoinducer-2 immunomodulatory molecule by pathogenic E.coli, which ultimately functions as a mediator of bacterial adhesion to intestinal cells, thus not allowing enteroinvasion ${ }^{13}$.

The beneficial effects and clinical applications of probiotics are the most diverse and are due to the most different mechanisms, among which we can highlight: reduction of intraluminal $\mathrm{pH}_{\text {, }}$ secretion of bactericins and defensins. This set of probiotic actions promotes antagonistic activity with enteropathogens and uropathogens ${ }^{10}$. The barrier function of the intestinal mucosa is enhanced by phosphorylation of actinin and ocludine at the narrow junctions and, also, by inhibiting apoptosis induced by cytokines ${ }^{28}$. Probiotics also induce the secretion of HeatShock Protein-70 (HSP-70), which are proteins present in the cytosol, which act as molecular guides in preventing protein aggregation and helping in the processing of antigens and their presentation ${ }^{15,25}$. Animal models demonstrated the protection exercised in spontaneous and chemically induced colitis through the "downregulation" of pro-inflammatory cytokines, related to specific strains. Other mechanisms identified were the reduction of CD4+ lymphocytes from the lamina propria and intraepithelial lymphocytes, inhibition of necrosis factor alpha (TNF-alpha), production of type 1 monocyte chemoattractive protein (MCP-1), in addition to increased production of interleukin-10 (IL-10) ${ }^{3,17}$.

Although probiotics perform functions ranging from immunomodulation to the bioavailability of neurotransmitters to the central nervous system, their effects on tissue repair in colonic anastomoses are still unknown.

The aim of this study wasto evaluate the effect of perioperative probiotic supplementation on the healing process of colonic anastomoses in rats.

\section{METHODS}

Thirty-six Wistar rats (Rattus norvegicus albinus, Rodentia Mammalia), adult males, with body weight varying between 220-320 $\mathrm{g}$, from the Vivarium of the State University of Maringá, Maringá, PR, Brazil, were used. The animals were housed and acclimated individually in boxes, receiving water and food ad libitum.

After initial acclimatization, the control group received food with ad libitum food for 14 days associated with the formula of maltodextrin $(n=18)$ at a dose of $250 \mathrm{~m} /$ day in an isocaloric and isovolumetric way. The probiotic study group $(n=18)$ received ad libitum food for two weeks. In the week preceding the surgical procedure (seven-day period) and in the postoperative period (five-day period), the rats of the study group received oral supplementation of probiotics at a dose of $250 \mathrm{mg} /$ day, associated with the isocaloric and isovolumetric diet.

The probiotic chosen for this study was composed of the strains Lactobacillus paracasei LPC-37, Bifidobacterium lactis HN0019, Lactobacillus rhamnosus HN001 and Lactobacillus acidophilus NCFM (doses 1x109 UFC/g)

The administration of probiotic or placebo was performed orally with the aid of a spatula with dosimeter containing the appropriate dose of the probiotic or maltodextrin administered directly (oral). Both groups underwent two colostomies, one in the right colon and the other in rectosigmoid, followed by reanastomosis with eight separate 6-0 mononylon stitches. The sacrifice took place on the fifth day. The parameters evaluated include tensile strength, collagen histology and densitometry.

Statistical analysis

Statistical analysis was performed using the T-Student and Mann-Whitney test with a $95 \%$ confidence interval $(\mathrm{Cl})$.

RESULTS

There was intestinal fistula in the rectosigmoid anastomosis in four animals (22.22\%) in the control group and two (11.11\%) in the probiotic group. The animals that presented fistula died.

\section{Tensiometric test}

To assess tensile strength, a computerized mechanical testing machine of the brand EMIC model DL 1000 (EMIC, São José dos Pinhais - PR) was used. The value of the maximum traction force (FMT) in the control group was $1.2 \pm 0.2 \mathrm{~N}$ and in the probiotic group it was $1.5 \pm 0.3 \mathrm{~N}, \mathrm{p}=0.025095 .27 \% \mathrm{Cl}$. The maximum breaking strength (FMR) of the control and probiotic groups were, respectively, $1.1 \pm 0.2 \mathrm{~N}$ and $1.4 \pm 0.3 \mathrm{~N}, \mathrm{p}=0.011695 .27 \%$ $\mathrm{Cl}$. Thus, it was possible to verify the positive impact on the use of the probiotic on the anastomosis tensile strength (Figure 1).

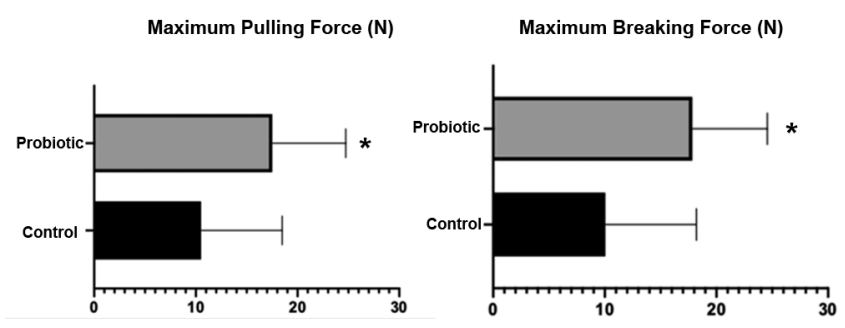

FIGURE 1 - Comparison between maximum pulling force (FMT) and maximum breaking force (FMR) between the control and probiotic groups. Data presented by mean \pm standard error. Mann-Whitney test * $\mathrm{p}<0.05$ compared with the control group. 
Histological evaluation and densitometry of collagen

The material was fixed in $10 \%$ formalin and processed for histopathological evaluation, with the following parameters being analyzed: area of inflammatory process, inflammatory infiltrate, fibrosis, vascular congestion, granulation tissue and edema, using $\mathrm{H} \& \mathrm{E}$ staining. The cuts were standardized at six micrometers thick. The analysis of collagen densitometry was obtained by staining Picrosirius Red 3FBA (PSR 3FBA) with automated reading by the GraphPad Prism 5 system.

In the H\&E analysis, there was no difference between the groups in relation to edema, vascular congestion and granulation tissue $(p>0.05)$; however, there was a significant difference $(p<0.05)$ for fibrosis and inflammatory infiltrate, as well as for the inflammatory process area (Figures 2 and 3 ).

\section{Fibrosis}

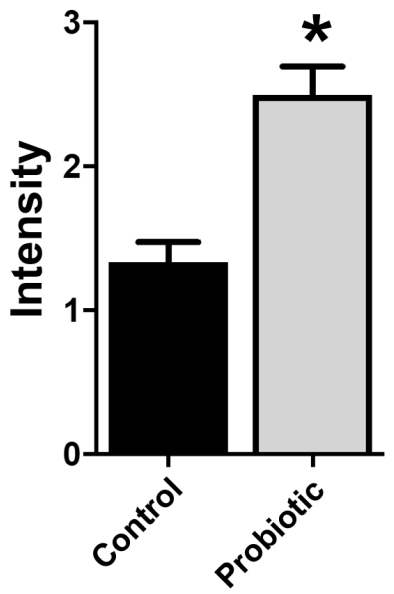

FIGURE 2 - Comparison between the histopathological indexes $(\mathrm{IH})$ of fibrosis between the control and probiotic groups. Data presented by mean \pm standard error. Student $T$ test. ${ }^{*} p<0.05$ compared to the control group

\section{Inflammatory infiltrate}

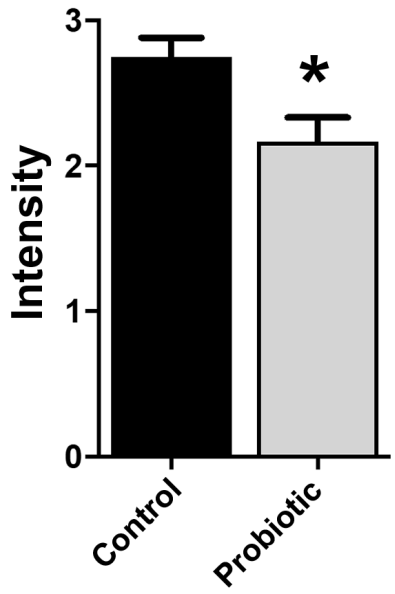

FIGURE 3 - Comparison between the histological indices (HI) of inflammatory infiltrate between the control and probiotic groups. Data presented by mean \pm standard error. Student T test. ${ }^{*} \mathrm{p}<0.05$ compared to the control group.

In the evaluation of PSR, the presence of collagen types I and III was significantly higher $(p<0.0001)$ in the probiotic group (Figures 4 and 5).

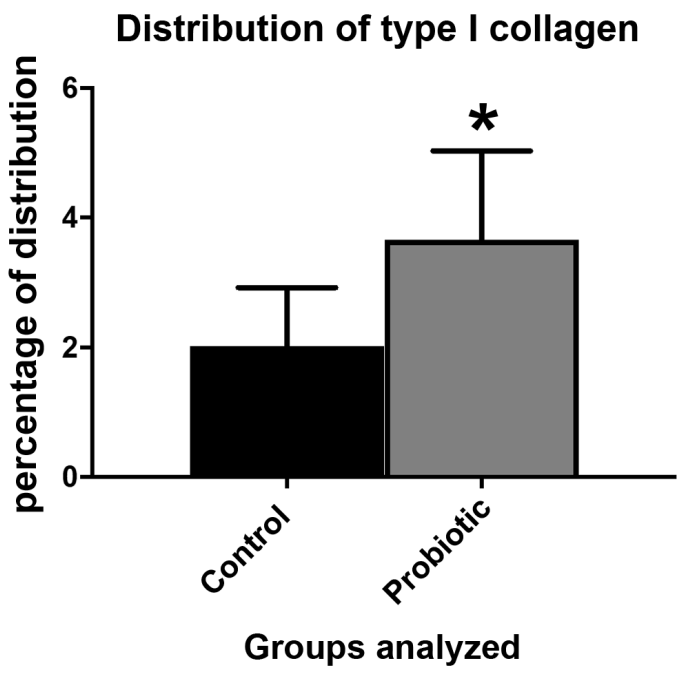

FIGURE 4 - Distribution of type I collagen (COL I) between control and probiotic groups. Data presented by mean \pm standard error. Student $T$ test. ${ }^{*} p<0.05$ compared to the control group.

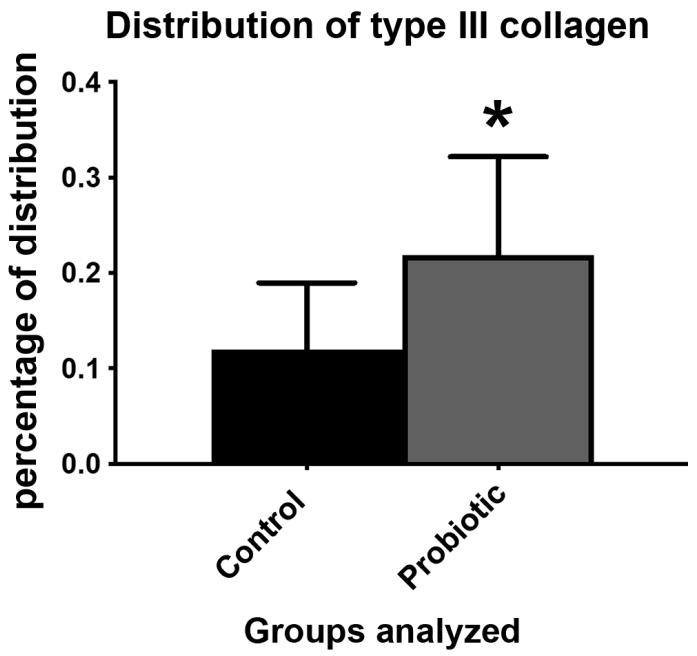

FIGURE 5 - Distribution of type III collagen (COL III) between control and probiotic groups. Data presented by mean \pm standard error. Student $T$ test. ${ }^{*} p<0.05$ compared to the control group.

\section{DISCUSSION}

The intestinal mucosa is a complex and dynamic system that functions as a semipermeable, allowing the passage of nutrients and macromolecules necessary for growth and development while protecting the bloodstream from potentially invasive microorganisms ${ }^{19}$. These basic functions occur in an environment inhabited by billions of commensal microorganisms from the three groups of living beings: Bacteria (Firmicutes, Bacteroidetes, Proteobacteria and Actinobacteria), which constitute about $96 \%$ of the intestinal microbiota, Archea and Eukarya, as well as viral particles $s^{1,720}$

The resection of a gastrointestinal segment is a common procedure for surgeons for a variety of reasons: gastroplasty, neoplasms, diverticular disease, inflammatory diseases, obstruction, etc. Considering intestinal anastomoses, all of its layers (from mucosa to serosa) will be sectioned and the tissue re-approximated with staplers and sutures. Thus, we will have "foreign bodies" in the healing line that act as antigens for our defense system.

Despite all the progress in terms of the means and materials to perform an operation (laparoscopy, robotics, etc), the surgeon's dexterity to perform the procedure with an appropriate technique, 
the rates of anastomotic fistulas have remained the same for over 60 years $^{23}$. In this sense, we seek to verify the possible contributing factors to these stable rates of complications. Both the species and the bacterial phenotype seem to be involved primarily in the complication.

The results obtained in the presentstudy suggest the presence of a more "organized" healing process with adequate intensity given the greater resistance in the tests of traction and collagen deposition obtained. In this same sense, it must be considered that the process was more effective taking into account that the probiotic group had a smaller area of inflammatory infiltrate than the control group. Among the processes involved is the expression of Toll-like receptors (TRLs) expressed by the commensal microbiota responsible for inducing chemokine with chemotactic activity and modulating the function of dendritic cells and T lymphocytes to promote and modulate wound healing ${ }^{31}$.

In a study conducted by Olivas et al. ${ }^{16}$, it was found that when subtypes with enteropathogenic characteristics of Pseudomonas aeruginosa were present at the anastomosis site, the fistula was present. When evaluating the mechanisms by which strains of Escherichia, Enterococcus and other groups of bacteria contribute to the formation of fistulas, increases in pore formation were found through $\mathrm{H} \& \mathrm{E}$, increased expression of the AIDA-I22 adhesion protein, direct cytotoxicity and through the release of tumor necrosis factor ${ }^{8,24}$, high motility and especially the increase in proteolytic activity of gelatinase, causing the degradation of the collagen matrix at the anastomosis site ${ }^{26}$. It has been observed that the intestinal anastomoses of animals treated with antibiotics considered "germ-free", when submitted to tensiometric tests, have a lower explosive strength or "burststregth" than animals not treated with antibiotics $12,14,29$, suggesting that the imbalance in the usual microbiota reduces the quality of the anastomosis. On the other hand, in other animal models that made empirical use of antibiotics, these proved to be useful in preventing fistulas when pathogenic bacteria or underlying diseases were present ${ }^{21}$.

\section{CONCLUSIONS}

Perioperative supplementation with probiotics was positively associated with increased deposition of types I and III collagen, increased tensile strength and area of fibrosis, even though there was initially an increase in the inflammatory infiltrate.

\section{REFERENCES}

1. Bäckhed F, LeyRE, Sonnenburg JL, Peterson DA, Gordon J. Host-bacterial mutualisminthehumanintestine.Science.2005Mar25;307(5717):1915-20.

2. Best J, Nijhout HF, Reed M. Serotonin synthesis, release and reuptake in terminals: a mathematical model. TheorBiol Med Model. 2010 Aug 19;7:34. doi: 10.1186/1742-4682-7-34.

3. Borchers AT, Selmi C, Meyers FJ, Keen CL, Gershwin ME. Probiotics and immunity. J Gastroenterol. 2009;44(1):26-46. doi: 10.1007/s00535-0082296-0.

4. Wagner NRF, Zaparolli MR, Cruz MRR, Schieferdecker MEM, Campos ACL. Mudanças na microbiota intestinal e uso de probióticos no pósoperatório de bypassgástrico em Y-de-Roux e gastrectomia vertical sleeve: uma revisão integrativa. ABCD ArqBrasCirDig. 2018;31(4):e1400. DOI: /10.1590/0102-672020180001e1400

5. CiorbaMA.Agastroenterologist'sguidetoprobiotics.ClinGastroenterolHepatol 2012 Sep;10(9):960-8. doi: 10.1016/j.cgh.2012.03.024

6. Desbonnet L, Garrett L, Clarke G, Bienenstock J, Dinan TG. The probiotic Bifidobacteriainfantis: An assessment of potential antidepressant propertiesintherat.JPsychiatrRes.2008Dec;43(2):164-74.doi:10.1016/j. jpsychires.2008.03.009.

7. Didari T, Mozaffari S, Nikfar S, Abdollahi M. Effectiveness of probiotics in irritablebowel syndrome:Updated systematic reviewwith meta-analysis. World J Gastroenterol. 2015 Mar 14;21(10):3072-84. doi: 10.3748/wjg. v21.i10.3072.

8. Eckburg PB, Bik EM, Bernstein CN, Purdom E, Dethlefsen L, Sargent M, Gill SR, Nelson KE, Relman DA. Diversity of the human intestinal microbial flora. Science. 2005 Jun 10:308(5728):1635-8.
9. FabbriA, Travaglione S, Fiorentini C. Escherichia coli cytotoxic necrotizing factor 1 (CNF1): toxin biology, in vivo applications and therapeutic potential.Toxins(Basel).2010Feb;2(2):283-96.doi:10.3390/toxins2020283.

10. FleissnerCK, Huebel N, Abd El-Bary MM, Loh G, Klaus S, BlautM. Absence of intestinal microbiota does not protect mice from diet-induced obesity. Br J Nutr. 2010 Sep;104(6):919-29. doi: 10.1017/S0007114510001303.

11. HüttP, Shchepetova J, Lõivukene K, KullisaarT, MikelsaarM. Antagonistic activity of probiotic lactobacilli and bifidobacteria against entero- and uropathogens. J Appl Microbiol. 2006 Jun;100(6):1324-32.

12. KauAL, AhernPP, Griffin NW, GoodmanAL, GordonJl.Humannutrition, the gutmicrobiomeandtheimmunesystem. Nature.2011 Jun15;474(7351):32736. doi: 10.1038/nature10213.

13. LeVeen HH, Wapnick S, Falk G, Olivas O, Bhat D, Gaurdre M, Patel M. Effects of prophylactic antibiotics on colonic healing. Am J Surg. 1976 Jan;131(1):47-53.

14. Mack DR, Michail S, Wei S, McDougall L, Hollingsworth MA. Probiotics inhibit enteropathogenic $E$. coli adherence in vitro by inducing intestinal mucin gene expression. Am J Physiol. 1999 Apr;276(4):G941-50. doi: 10.1152/ajpgi.1999.276.4.G941.

15. Mastboom WJ, Hendriks T, de Boer $\mathrm{HH}$. Collagen changes around intestinalanastomosesingerm-freerats.BrJSurg. 1989Aug;76(8):797-801.

16. Multhoff G. Heat shock protein 70 (Hsp70): membrane location, export and immunological relevance. Methods. 2007 Nov;43(3):229-37.

17. Olivas AD, Shogan BD, Valuckaite V, Zaborin A, Belogortseva N,Musch $M$, Meyer F, Trimble WL, An G, Gilbert J, Zaborina O, Alverdy JC. Intestinal tissues induce an SNP mutation in Pseudomonas aeruginosa that enhances its virulence: possible role in anastomotic leak. PLoS One. 2012;7(8):e44326. doi: 10.1371/journal.pone.0044326.

18. Roselli M, Finamore A, Nuccitelli S, Carnevali P, Brigidi P, Vitali B, Nobili F, Rami R, Garaguso I, Mengheri E. Prevention of TNBS-induced colitis by different Lactobacillus and Bifidobacterium strains is associated with an expansion of gammadeltaT and regulatory $T$ cells of intestinal intraepithelial lymphocytes. Inflamm Bowel Dis. 2009 Oct;15(10):152636. doi: 10.1002/ibd.20961.

19. Sanders ME. Probiotics: definition, sources, selection, and uses. Clin Infect Dis. 2008 Feb 1;46 Suppl 2:S58-61; discussion S144-51. doi: 10.1086/523341.

20. SandersonIR, WalkerWA.Uptakeand transportofmacromolecules bythe intestine: possible rolein clinical disorders (an update). Gastroenterology. 1993 Feb;104(2):622-39.

21. Scanlan PD, Marchesi JR. Micro-eukaryotic diversity of the human distal gut microbiota: qualitative assessment using culture-dependent and -independent analysis of faeces. ISME J. 2008 Dec;2(12):1183-93. doi: 10.1038/ismej.2008.76

22. Schardey HM, Krämling HJ, Cramer C, Kusenack U, Hadersbeck J, Schildberg FW. [Risk factors and pathogenic microorganisms in patients withinsufficientesophagojejunostomyaftergastrectomy].ZentralblChir. 1998;123(1):46-52.

23. Sherlock O, Schembri MA, Reisner A, Klemm P. Novel roles for the AIDA adhesin from diarrheagenic Escherichia coli: cell aggregation and biofilm formation. J Bacteriol. 2004 Dec;186(23):8058-65.

24. Shogan BD, Smith DP, Christley S, Gilbert JA, Zaborina O, Alverdy JC. Intestinalanastomoticinjuryaltersspatiallydefinedmicrobiomecomposition and function. Microbiome. 2014 Sep 15:2:35. doi: 10.1186/2049-26182-35. eCollection 2014

25. Smith JL, Bayles DO. The contribution of cytolethal distending toxin to bacterial pathogenesis. Crit Rev Microbiol. 2006 Oct-Dec;32(4):227-48.

26. TaoY, DrabikKA, Waypa TS, MuschMW, AlverdyJC, SchneewindO, Chang EB, Petrof EO. Soluble factors from Lactobacillus GG activate MAPKs and induce cytoprotective heat shock proteins in intestinal epithelial cells. Am J Physiol Cell Physiol. 2006 Apr;290(4):C1018-30.

27. Waters CM,AntiportaMH,MurrayBE,DunnyGM. RoleoftheEnterococcus faecalisGelEproteaseindetermination ofcellularchainlength, supernatant pheromone levels, and degradation of fibrin and misfolded surface proteins. J Bacteriol. 2003 Jun;185(12):3613-23.

28. Woting A, Pfeiffer N, Loh G, Klaus S, Blaut M. Clostridium ramosum promotes high-fat diet-induced obesity in gnotobiotic mouse models. MBio. 2014 Sep 30;5(5):e01530-14. doi: 10.1128/mBio.01530-14.

29. Álvaro $M$, Lins-Neto $F$, Jurema Da M, Leão R, Alves EC, Fontan AJ, et al. Colonmechanicalpreparationisnecessary as routine in medical care? ABCD Arq Bras Cir Dig, 2012;25(1): 25-28.

30. deOliveiraAL,AarestrupFM. Nutritional statusand systemicinflammatory activity of colorectal patients on symbiotic supplementation. Arq Bras Cir Dig. 2012 Jul-Sep;25(3):147-53. English, Portuguese. doi: 10.1590/ s0102-67202012000300003. PMID: 23411802.

31. Tagliari E, Campos LF, Campos AC, Costa-Casagrande TA, Noronha L. Efeito da administração oral de probióticos na cicatrização de feridas cutâneas em ratos. ABCD Arq Bras Cir Dig. 2019;32(3):e1457. DOI: /10.1590/0102-672020190001e1457 